FKIP Universitas Kuningan

\title{
MEMANFAATKAN WHATSAPP SEBAGAI MEDIA DALAM KEGIATAN LITERASI DI MASA PANDEMI COVID-19
}

\author{
Aswan \\ Program Studi Pendidikan Bahasa dan Sastra Indonesia \\ Fakultas Pendidikan Bahasa dan Sastra \\ Universitas Pendidikan Indonesia \\ hikayatashwansha@upi.edu
}

\begin{abstract}
ABSTRAK: Munculnya pandemi Covid-19 di Indonesia memiliki dampak yang sangat signifikan terhadap dunia pendidikan. Hal ini dapat dilihat pada perkembangan pendidikan di Indonesia yang berjalan sangat pasif. Pembelajaran konvensional terpaksa diganti dengan pembelajaran jarak jauh via daring. Selain dari pembelajaran formal, aktivitas literasi juga terdampak oleh pandemi Covid-19. Salah satu cara agar pembelajaran berjalan sesuai dengan standar, maka semua elemen pendidikan harus memanfaatkan teknologi dalam menghubungkan antara guru dan siswa. Melihat hal tersebut, penelitian ini bertujuan untuk menggambarkan bagaimana pemanfaatan WhatsApp yang digunakan sebagai media kegiatan literasi di masa pandemi Covid-19. Metode penelitian yang digunakan adalah metode kualitatif. Jumlah partisipan dalam penelitian ini berjumlah 233 orang. Berdasarkan hasil analisis, dapat dikatakan bahwa dengan memanfaatkan WhatsApp sebagai media dalam aktivitas literasi dapat memantik minat masyarakat dari berbagi jenjang, mulai dari siswa, mahasisa, pekerja rumah tangga, guru, dan lain-lain. Salah satu aktivitas literasi yang dilakukan dalam grup WhatsApp adalah pelatihan menulis judul cerita berbantuan gambar. Kesimpulan yang dapat diambil adalah WhatsApp dapat dijadikan sebuah media dalam kegiatan berliterasi di masa pandemi Covid-19.
\end{abstract}

KATA KUNCI: Covid-19; kegiatan literasi; pemanfaatan WhatsApp.

\section{UTILIZING WHATSAPP AS A MEDIA IN LITERACY ACTIVITIES IN THE COVID-19 PANDEMIC PERIOD}

\begin{abstract}
The emergence of the Covid-19 pandemic in Indonesia has had a very significant impact on the world of education. This can be seen in the development of education in Indonesia which runs very passively. Conventional learning has to be replaced with distance learning via online. Apart from formal learning, literacy activities have also been affected by Covid-19 pandemic. One way for learning to run according to standards, all elements of education must take advantage of technology in connecting teachers and students. Seeing, this study aims to describe how the use of WhatsApp is used as a medium for literacy activities during the Covid-19 pandemic. The research method used is a qualitative method. The number of participants in this study amounted to 233 people. Based on the results of the analysis, it can be said that using WhatsApp as a medium in literacy activities can spark people's interest from sharing levels, starting from students, students, domestic workers, teachers, and others. One of the literacy activities carried out in the WhatsApp group is training in writing story titles aided by images. The conclusion that can be drawn is that WhatsApp can be used as a medium for literacy activities during the Covid-19 pandemic.
\end{abstract}

KEYWORDS: Covid-19; literacy activities; use of WhatsApp.

\begin{tabular}{lccc}
\hline Diterima: & Direvisi: & Distujui: & Dipublikasi: \\
16-09-2020 & - & $01-10-2020$ & $28-10-2020$ \\
& & \\
Pustaka : Aswan (2020). Memanfaatkan whatsapp sebagai media dalam kegiatan literasi di masa pandemi \\
covid-19. Fon : Jurnal Pendidikan Bahasa dan Sastra Indonesia, 16(2), 65-78. \\
DOI $\quad:$ https://doi.org/10.25134/fjpbsi.v16i2.3469
\end{tabular}

\section{PENDAHULUAN}

Indonesia menjadi salah satu negara yang terdampak oleh pandemi Covid-19. Seperti yang terlansir dalam berita Kompas.com, Presiden Joko Widodo mengumumkan pertama kali kasus Covid19 di Istana Kepresidenan pada tanggal 2 Maret 2020 Sejak dari itu sampai dengan tanggal 1 September 2020, Kementerian Kesehatan Republik Indonesia 
mengungkapkan data bahwa sebanyak 177.571 orang yang terjangkiti oleh Covid-19 (Ihsanuddin, 2020; Fatia, 2020).

Hadirnya pandemi Covid-19 di Indonesia sangat berdampak bagi dunia pendidikan. Melihat kondisi Indonesia yang tidak kunjung membaik, maka salah satu cara untuk menghidupkan pendidikan adalah dengan cara pendidikan jarak jauh. Teknologi menjadi sarana penghubung antarguru dan siswa. Tidak ada pembelajaran tatap muka di sekolah. Semua pembelajaran diarahkan secara daring. O'Sullivan (2020) mengungkapkan bahwa wabah Covid-19 yang menyerang dunia saat ini sangat berdampak pada sektor pendidikan. Guru harus mengajar dari rumah dan siswa harus belajar dari rumah. Semua civitas akademika di dalam lingkup pendidikan harus mencari metode dan strategi yang tepat dalam menghidupkan pendidikan di masa pandemi Covid-19.

Selain pendidikan formal yang terdampak Covid-19, kegiatan literasi juga merasakan dampak yang sama. Satusatunya cara agar kegiatan literasi terus berjalan adalah dengan memanfaatkan teknologi sebagai sarana penghubung. Dhawan (2020) mengungkapkan bahwa adanya pembelajaran jarak jauh atau dikenal juga sebagai pembelajaran daring dapat mengembangkan keterampilan baru dalam proses belajar mengajar. Hal ini yang sebenarnya ingin peneliti adopsi menjadi sebuah asumsi berpikir dalam mencari solusi yang tepat untuk mewujudkan kegiatan literasi di masa pandemi Covid-19.

Literasi saat ini sering diartikan sebagai kegiatan membaca dan menulis. Kedua kegiatan berbahasa ini tidak pernah lepas dari kegiatan berliterasi. Konsep melek aksara atau keberaksaraan menjadi dasar dalam konsep literasi. Sederhananya, literasi ini selalu mengacu pada konsep-konsep keterampilan membaca dan menulis. Jika dilihat pada pengertian yang lebih luas, dapat dikatakan bahwa literasi adalah kegiatan yang bertujuan mengasah pola pikir manusia melalui keterampilan membaca dan menulis. Dari keterampilan tersebut dapat dimanfaatkan pada kehidupan sehari-hari (Suwandi, 2018).

Seturut dengan konsep literasi yang sudah dijelaskan, Budhianto (2018) mengatakan bahwa keterampilan berbahasa khususnya membaca dan menulis merupakan faktor yang sangat penting dalam proses pembelajaran formal di sekolah. Dengan berbahasa siswa dapat memperoleh informasi. Keterampilan berbahasa yang merupakan konsep awal dari literasi merupakan dasar dari kegiatan belajar mengajar di sekolah.

Literasi dan kegiatan belajar tidak dapat dipisahkan meskipun kedua konsep tersebut memiliki ruang yang berbeda dalam penyelenggaraannya saat ini. Kegiatan Literasi biasanya terletak di luar pembelajaran formal. Aktivitas literasi biasanya berada di luar jam-jam pembelajaran, seperti membaca buku 15 menit sebelum pembelajaran dimulai. Jauh dari itu, kegiatan di luar sekolah banyak dilakukan oleh pegiat-pegiat literasi seperti kelas menulis, kelas menerbitkan buku, kegiatan literasi lainnya. Melihat kondisi pandemi Covid19 yang semakin mewabah di Indonesia, maka kegiatan berliterasi pun tidak bisa dilaksanakan seperti biasanya. Meskipun demikian, aktivitas berliterasi di luar jam sekolah perlu dilaksanakan karena literasi memiliki urgensi yang jelas dalam membangun bangsa. Misalnya pada keterampilan membaca, anak-anak Indonesia masih jauh di bawah rata-rata. Salah satu upaya yang harus dilakukan adalah dengan mewujudkan budaya literasi (Aulia, dkk., 2020; Aswan, 2020).

Teknologi merupakan salah satu solusi dalam mewujudkan budaya literasi di masa pandemi Covid-19 ini. Platform digital dapat dimanfaatkan sebagai media 
pembelajaran khsusunya di bidang literasi. Pemanfaatan platform digital secara daring dapat meningkatkan konektivitas dan mewujudkan kolaborasi dan peluang berkarya (Mihailidis, 2016). Seturut dengan pendapat tersebut, Nelson et. al. (2020) mengungkapkan bahwa aktivitas literasi berbasis digital lebih mendominasi produktivitas belajar dari pembelajaran tatap muka. Asumsi tersebut memang perlu dibuktikan dengan memanfaatkan digitalisasi ke dalam aktivitas berliterasi.

Penggunaan teknologi dalam pembelajaran saat ini sangat relevan karena teknologi tumbuh dalam kehidupan anak-anak yang hidup di zaman ini. Teknologi dapat dimanfaatkan dalam mengisi waktu luang, bermain, serta berinteraks dengan orang lain. Selain itu, teknolog saat ini dapat dimanfaatkan semua orang dalam menambah pengetahuan baru. Khususnya pada media digital dapat menambah pengalaman multiliterasi karena dari media digital tersebut dapat diakses apa saja (Chaudron, 2015; Danby dkk., 2018; Erstad dkk. 2020; Fleer, 2018; Flewitt dkk. 2015; Kumpulainen $d k k$., 2020; Marsh $d k k$, 2017.

Menurut Adelore (2017) teknologi dan literasi sangat berkaitan karena untuk menggunakan teknologi harus memiliki pengetahuan literasi yang memadai. Meskipun begitu, untuk menambah pengetahuan literasi teknologi juga memiliki peran yang sangat penting. Hal ini berjalan secara timbal balik sehingga tidak dapat dipisahkan. Salah satu media yang dapat menjadi jembatan untuk kegiatan literasi adalah WhatsApp. WhatsApp dapat dijadikan media dalam kegiatan pembelajaran. Sejalan dengan asumsi tersebut, Wijaya (2018) mengungkapkan bahwa pembelajaran daring seharusnya memanfaatkan aplikasi yang mudah diakses oleh pengajar dan pembelajar. Salah satu aplikasi yang sangat dekat dengan manusia saat ini adalah WhatsApp. Kurniati dan Nuryani (2020) menjelaskan bahwa hampir setiap orang memiliki gawai untuk berkomunikasi dan seiring berjalannya waktu, gawai tidak hanya digunakan untuk berkomunikasi melainkan untuk pembelajaran. Hal inilah yang menjadi dasar peneliti dalam berpikir bahwa WhatsApp dapat dijadikan media dalam kegiatan berliterasi di luar konteks pembelajaran formal.

Menurut Rahmansari (2017) aplikasi WhatsApp menjadi aplikasi mengirim pesan paling diminati oleh masyarakat Indonesia. Aplikasi WhatsApp menjadi yang terdepan dari aplikasi mengirim pesan lainnya. WhatsApp menjadi salah satu aplikasi yang paling aktif digunakan di dunia dan telah banyak digunakan dalam kepentingan pendidikan (AlFaris, dkk., 2019; Jamal, dkk., 2016; Goyal, dkk., 2017; Raiman, dkk., 2017). Melihat populeritas dan fungsi dari aplikasi WhatsApp, maka tidak heran jika aplikasi ini dapat menjadi media dalam kegiatan berliterasi di masa pandemi Covid19.Sejalan dengan gagasan di atas, Pustikayasa (2019) mengungkapkan bahwa aplikasi WhatsApp merupakan salah satu aplikasi yang revelan di gunakan dalam pembelajaran karena di dalam aplikasi WhatsApp memiliki fitur grup yang memungkinkan orang berkelompok.

Penelitian terdahulu mengenai pemanfaatan dan penggunaan WhatsApp untuk pembelajaran pernah diteliti oleh Ganasegeran, $d k k$. (2017) berjudul The mHealth Revolution: Exploring Perceived Benefits of WhatsApp Use in Clinical Practice". Penelitian tersebut mengungkapkan bahwa penggunaan WhatsApp dalam pembelajaran praktisi 307 orang tim medis bermanfaat dan efektif digunakan dalam menjalin komunikasi antar tim medis dengan pasien. Adanya WhatsApp dapat membantu tim medis dalam 
berkomunikasi dengan pasien yang sedang dirawat.

Penelitian yang relevan juga pernah dilakukan oleh Costa-Sánchez dan Guerrero-Pico (2020) berjudul "What Is WhatsApp for? Developing Transmedia Skills and Informal Learning Strategies Through the Use of WhatsApp - A Case Study With Teenagers From Spain". Penelitian tersebut menggungkapkan bahwa pemanfaatan WhatsApp dalam strategi pembelajaran interpesonal dapat mengembangkan siswa menjadi produktif, bersosial, dan dapat mengatur waktu dengan baik karena keseharian mereka tidak pernah lepas dari WhatsApp.

Penelitian yang berfokus pada efektivitas penggunaan WhatsApp pernah diteliti oleh Fattah (2015) berjudul " The Effectiveness of Using WhatsApp Messenger as One of Mobile Learning Techniques to Develop Students' Writing Skills". Penelitian ini menjelaskan pengaruh WhatsApp terhadap pembelajaran keterampilan menulis siswa. Hasil penelitian menggambarkan bahwa WhasApp memberikan pengaruh yang signifikan terhadap keterampilan menulis siswa. Hal tersebut dibuktikan dengan unggulnya kelompok eksperimen dari kelompok kontrol.

Berdasarkan penelitian terdahulu, perlu kiranya digarisbawahi hal-hal yang belum diteliti dan dikaji. Penelitian terdahulu hanya berfokus untuk mengetahui bagaimana pemanfaatan WhatsApp pada pembelajaran tertentu dan tidak menyinggung perihal aktivitas literasi di masa pandemi Covid-19. Hal tersebut kemudian menjadi kerangka berpikir dalam penelian ini. Penelitian yang akan dilakukan ini berfokus pada pemanfaatan WhatsApp sebagai media untuk mewujudkan budaya literasi di tengah pandemi Covid-19. Inilah yang menjadi kekurangan dari penelitian terdahulu, sehingga otomatis menjadi kelebihan dalam penelitian ini. Melalui telusuran pustaka yang sudah peneliti lakukan, penelitian terkait pemanfaatan WhatsApp sebagai media dalam kegiatan berliterasi di masa pandemi Covid-19 belum pernah dilakukan sehingga penelitian ini dapat terjamin orisinalitasnya.

Seturut dengan asumsi dari peneliti, Scolari dan Contreras-Espinosa (2020) menjelaskan bahwa kunci dalam menghidupkan budaya literasi yang konteksnya di luar pembelajaran formal terletak pada strategi dan media yang tepat. Dengan demikian, pemanfaatan WhatsApp sebagai media dalam kegiatan berliterasi di masa pandemi Covid-19 penting untuk dilakukan. Harapan dari penelitian ini adalah dapat memberi solusi untuk pegiat literasi di masa pandemi Covid-19 dalam mewujudkan gerakan literasi.

\section{METODE}

Metode penelitian yang digunakan adalah metode kualitatif. Peneliti memilih metode ini karena sesuai dengan tujuan penelitian yakni ingin menggambarkan bagaimana proses pemanfaatan WhatsApp sebagai media dalam mewujudkan kegiatan literasi di masa pandemi Covid19. Seturut dengan hal tersebut, Creswell (2009) menggungkapkan bahwa penelitian kualitatif adalah sarana untuk mengeksplorasi dan memahami individu atau kelompok yang menjadi subjek atau objek dalam penelitian. Hakikat dari penelitian kualitatif ini adalah tidak menghasilkan prosedur analisis berbentuk angka dan data model statistika (Meleong, 2012).

Subjek dalam penelitian ini adalah peserta kegiatan literasi yang mengikuti kelas menulis daring Penerbit Aryasena. Subjek yang dijadikan responden dalam penelitian ini berjumlah 233 partisipan yang terdiri dari berbagai jenjang. Melihat kelas menulis ini yang bersifat daring memungkinkan partisipan dari berbagai 
daerah bergabung. Partisipan terdiri atas siswa, mahasiswa, guru, ibu rumah tangga dan lain-lain. Adanya partisipan yang heterogen membuat kelas menulis daring ini menjadi menarik. Objek dalam penelitian ini adalah pemanfaatan WhatsApp sebagai media dalam mewujudkan kegiatan literasi di masa pandemi Covid-19.

Data diperoleh dari hasil pengamatan selama kegiatan literasi menggunakan aplikasi WhatsApp. Data yang terkumpul berupa dokumentasi, catatan kejadian, dan respons responden. Data diuraikan dalam bentuk naratif berupa alur dan konsep dasar kegiatan literasi menggunakan WhatsApp, prosedur penggunaan WhatsApp dalam aktivitas berliterasi di masa pandemi Covid-19, dan respons partisipan terhadap penggunaan WhatsApp dalam kegiatan literasi.

Pengumpulan data dilakukan dengan cara: 1) menyusun asumsi dasar penelitian; 2) memanfaatkan WhatsApp sebagai media dalam aktivitas literasi; 3) peneliti mengamati kegiatan; 4) peneliti mencatat dan merekam aktivitas yang terjadi selama kegiatan literasi menggunakan WhatsApp; 5) peneliti meminta timbal balik dari responden terkait kesan dan pesan dari aktivitas literasi yang sudah dilaksanakan; 6) peneliti menganalisis data menginterpretasi data; 7) peneliti membuat simpulan terkait hasil temuan penelitian.

\section{HASIL DAN PEMBAHASAN}

\section{Alur Pemanfaatan WhatsApp dalam} Kegiatan Literasi

Pada bagian ini, peneliti akan menguraikan bagaimana alur pemanfaatan aplikasi WhatsApp dalam aktivitas literasi di masa pandemi Covid-19. Agar lebih jelas, diilustrasikan sebagai berikut

Gambar 1. Alur Aktivitas Literasi Menggunakan WhatsApp
Membuat Grup WhatsApp

Sosialisasi Kegiatan

Menyusun Kegiatan

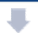

Pelaksanaan

5

Evaluasi: Respons Partisipan

Penutup

Langkah pertama dalam mewujudkan gerakan literasi di masa pandemi Covid-19 adalah membuat grup WhatsApp. Hal ini menjadi dasar dari pembelajaran yang akan dilaksanakan. Grup WhatsApp dibuat sesuai dengan nama dari gerakan literasi yang dilaksanakan oleh Kelas Menulis Penerbit Aryasena. Gambarannya sebagai berikut.

Gambar 2. Grup Whatsapp Kelas Menulis Aryasena

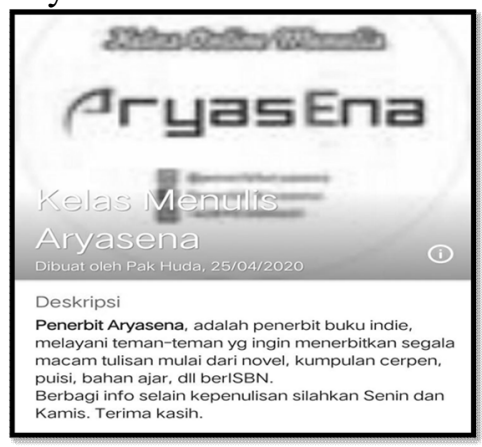

Langkah kedua dalam mewujudkan gerakan literasi di masa pandemi Covid19 adalah dengan menyosialisasikan kepada masyarakat terkait kelas menulis daring yang telah dirancang. Kelas menulis yang digagas oleh Penerbit Aryasena ini dibuka untuk semua jenjang sehingga semua generasi berpeluang untuk mengikuti. Hal ini diharapkan dapat mewujudkan budaya literasi tidak hanya pada kalangan anak muda saja. Namun, 
diharapkan semua generasi dapat berpartisipasi. Sejak awal sampai akhir pendaftaran, peserta yang bergabung berjumlah 233, ditambah peneliti dan moderator jadi total jumlah 235 orang yang tersebar dari seluruh Indonesia. Peserta berasal dari berbagai jenjang, mulai dari siswa, mahasiswa, guru, ibu rumah tangga, dan lain-lain. Berikut ilustrasinya.

Gambar 3. Peserta Kelas dalam Grup WhatsApp

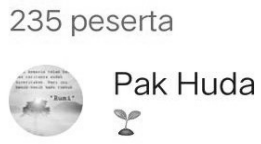

Tahapan ketiga adalah peneliti membuat rancangan pembelajaran. Perancangan dibuat berdasarkan waktu yang sudah ditetapkan oleh penyelenggara. Waktu yang digunakan dalam aktivitas literasi ini berdurasi satu jam tiga puluh menit. Dimulai dari pengenalan sampaikan dengan penutup. Peneliti berperan sebagai pemateri dalam penelitian ini dengan dibantu oleh seorang moderator. Berikut ilustrasi pelaksanaan kegiatan literasi menggunakan WhatsApp.

Gambar 4. Rancangan Gerakan Literasi Menggunakan Whatsapp

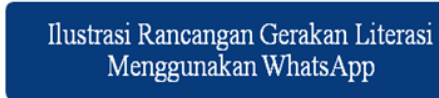

Pengenalan oleh Moderator (10 menit)

Materi Pembukaan (15 menit)

\section{Materi Inti (45 menit)}

\section{乎}

Timbal Balik Partisipan (10 menit)

\section{Penutup (10 menit)}

Pelaksanaan kegiatan literasi dimulai dari pembukaan dari moderator. Pada sesi ini, moderator menjelaskan aturan-aturan apa saja yang harus dipatuhi selama kegiatan literasi berlangsung. Aturan umum yang wajib dipatuhi selama kegiatan berlangsung adalah partisipan tidak boleh membuat forum lain yang tidak sesuai dengan instruksi moderator. Selain itu, partisipan tidak boleh mengunggah apa pun di dalam grup WhatsApp tanpa izin dari moderator. Partisipan wajib mengikuti instruksi dari moderator dan pemateri. Hal ini diharapkan dapat menertibkan suasana kelas daring yang dihadiri oleh ratusan partisipan. Waktu yang digunakan moderator dalam mengondisikan kelas berdurasi sepuluh menit. Agar menjadi lebih jelas, maka alur dari perancangan diuraikan sebagai berikut.

Gambar 5. Pembukaan oleh Moderator (10 Menit)

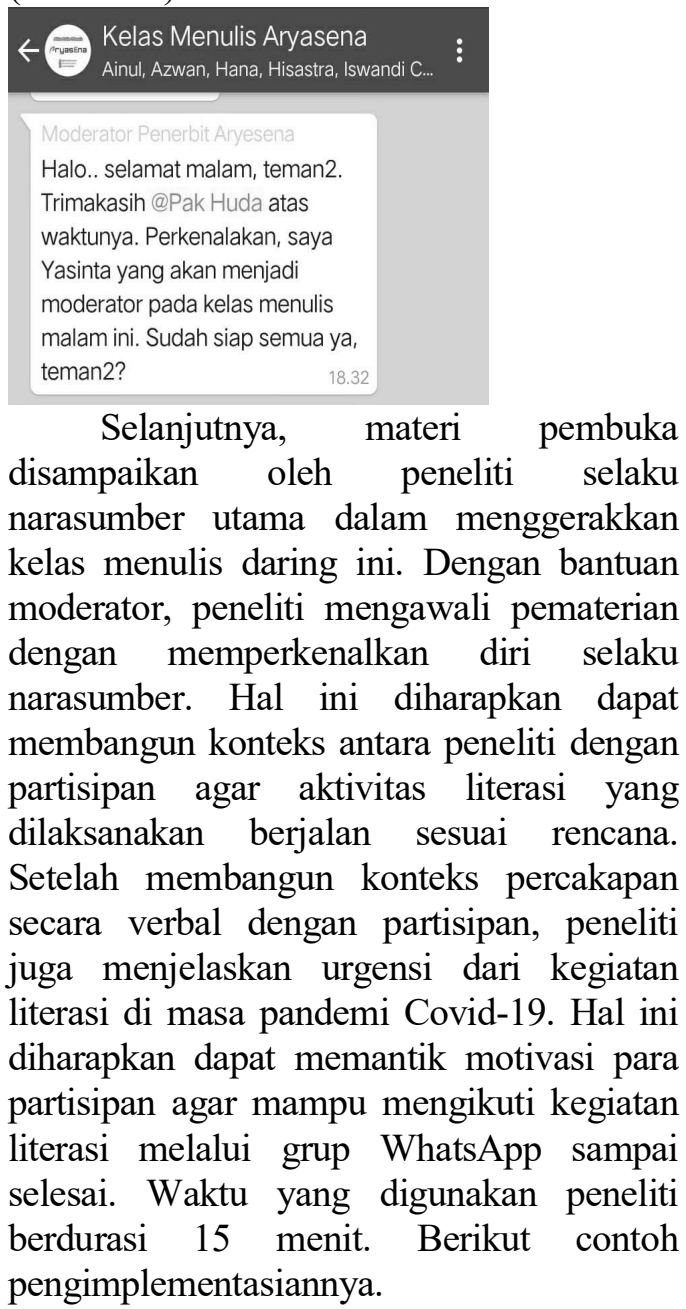


Gambar 6. Materi Pembukaan dari

Peneliti (15 Menit)

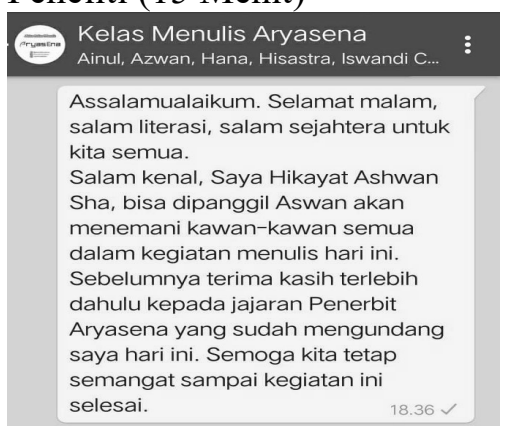

Sesi utama aktivitas literasi dalam kelas menulis yang digagas oleh penerbit Aryasena adalah dengan memberikan materi dasar kepenulisan. Salah satu materi yang menjadi fokus penerbit dan peneliti adalah terkait penulisan judul. Pada awal pematerian, peneliti memantik peserta dengan dua contoh penulisan judul tulisan yang dibuat secara acak dan sudah disesuaikan dengan Pedoman Umum Ejaan Bahasa Indonesia (PUEBI).

Judul pertama "Kumenangis Membayangkan" dan judul kedua "Cintaku Bukan di Atas Kertas". Kedua judul ini dipilih berdasarkan hal yang sedang viral di media sosial. Judul pertama merupakan lirik lagu dari penyanyi Indonesia bernama Rossa yang sempat viral di media sosial. Lagu tersebut viral karena sebuah tayangan senetron Indonesia yang bertemakan isi hati seorang perempuan. Hal ini sangat relevan untuk dijadikan judul dalam memantik partisipan dalam memahami teori dasar dalam menulis judul. Kemudian, topik judul kedua diambil lirik lagu penyanyi Malaysia bernama Siti Nurhaliza yang berjudul Bukan Cinta Biasa. Lagu tersebut sempat viral lantas banyak yang menggunakan sebagai instrumen di aplikasi Tiktok. Kedua judul ini diharapkan mampu menarik minat partisipan dalam menjawab pertanyaan peneliti berikut, Judul manakah yang benar penulisannya? Berikut gambaran dari stimulus awal dalam menulis judul tulisan yang benar.

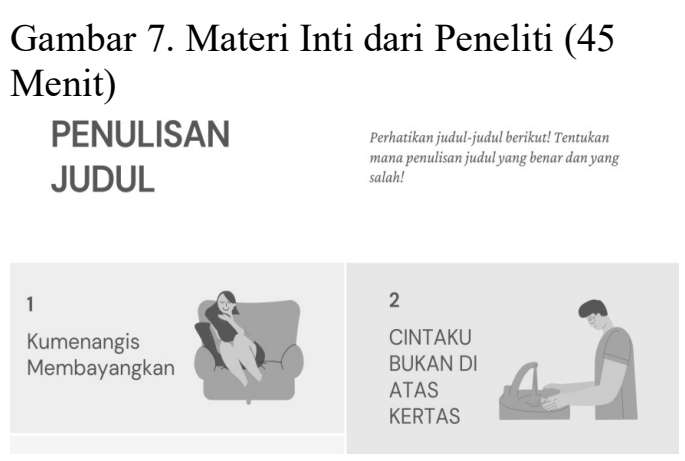

Tabel 1. Materi Dasar Penulisan Judul

\begin{tabular}{|l|l|}
\hline Huruf Kapital & Huruf Kapital \\
Semua Unsur & Digunakan Setiap \\
Kata & Awal Unsur Kata \\
& Kecuali Preposisi, \\
& Konjungsi, Kata \\
& Ulang Tidak \\
& Sempurna, dan \\
& Interjeksi \\
\hline Contoh: & Contoh: \\
SITI & Siti Nurbaya \\
NURBAYA & Laskar Pelangi \\
LASKAR & \\
PELANGI & \\
\hline
\end{tabular}

Sumber: PUEBI daring

Berdasarkan tabel 1. di atas, materi yang disampaikan adalah materi umum dalam menulis judul tulisan yang benar. Hal ini menjadi sangat penting untuk disampaikan karena hal ini menjadi dasar dalam menulis, baik tulisan berupa fiksi maupun nonfiksi. Kegiatan literasi tidak serta-merta berkaitan dengan membaca, tetapi juga berkaitan erat dalam mengetahui, mengolah, dan mencipta. Berdasarkan materi umum yang diberikan, diharapakan partisipan memiliki pengetahun dasar dalam menulis judul agar mampu mengaplikasikan di dalam kehidupan sehari-hari. Melihat bahwa menulis judul tidak akan pernah lepas dalam konteks sosial masyarakat. Minimal partisipan dapat mengaplikasikan dalam kegiatan menulis judul status yang di media sosial. 
Setelah pemberian materi seputar penulisan judul selesai. Peneliti sekali lagi memantik partisipan untuk menuangkan idenya dalam menulis judul. Pada sesi berikutnya, peneliti memberikan partisipan stimulus berupa 3 buah ilustrasi berupa gambar yang berbeda. Ketiga ilustrasi ini digunakan untuk memancing kreativitas partisipan dalam menulis judul yang benar. Ada dua aspek yang diperhatikan dalam sesi ini. Pertama, partisipan diharapkan mampu menulis judul yang benar sesuai Pedoman Umum Ejaan Bahasa Indonesia (PUEBI). Kedua, dengan adanya stimulus yang diberikan berupa ilustrasi, diharapkan mampu memacu partisipan dalam menggali ide dan menuangkannya ke dalam tulisan. Berikut ilustrasinya yang digunakan.

Gambar 8. Stimulus Pertama

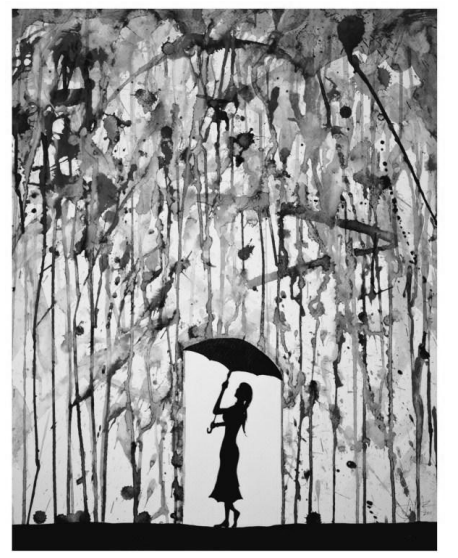

(Sumber: Google.com)

Gambar 9. Stimulus Kedua

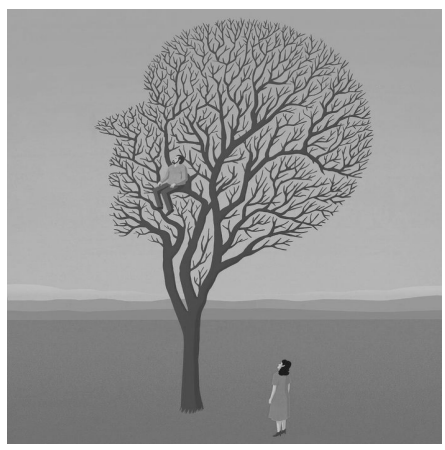

(Sumber: Google.com)
Gambar 10. Stimulus Ketiga

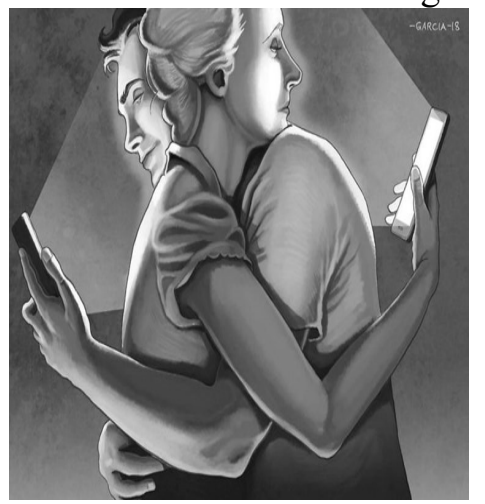

(Sumber: Google.com)

Pemilihan stimulus dilakukan secara acak yang diunduh dari Google.com. Berdasarkan stimulus yang sudah diberikan, partisipan terlihat berlomba-lomba dalam mengaplikasikan bagaimana cara menulis judul yang benar. Ketiga stimulus yang diberikan berhasil memantik pertisipan dalam menerapkan cara menulis judul yang benar menurut PUEBI. Berikut beberapa respons partisipan yang diambil secara acak selama aktivitas menulis dilaksanakan.

Gambar 11. Respons dari Stimulus

Pertama

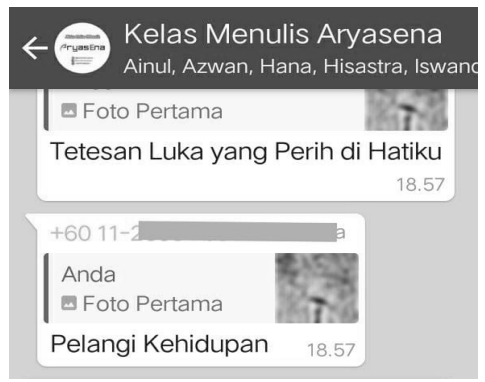

Gambar 12. Respons dari Stimulus Kedua

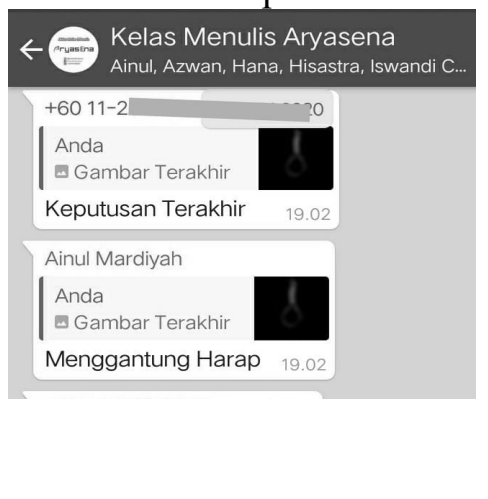


Gambar 13. Respons dari Stimulus Ketiga

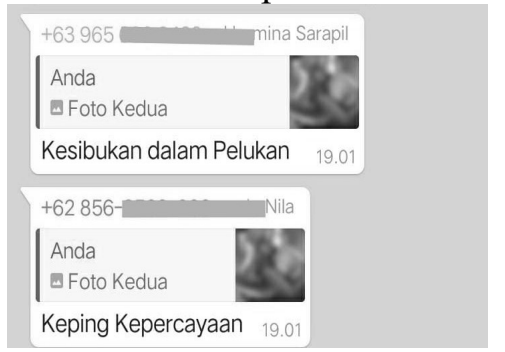

Berdasarkan gambar di atas, dapat dilihat bahwa partisipan sangat antusias dalam menulis judul cerita. Adapun juduljudul yang terlhat pada gambar di atas seperti berikut: Tetesan Luka yang Perih di Hatiku, Pelangi Kehidupan, Keputusan Terakhir, Menggantung Harap, Kesibukan dalam Pelukan, Keping Kepercayaan.

Tahapan keempat adalah peneliti mengevaluasi pembelajaran yang telah dilakukan. Evaluasi yang dilakukan adalah dengan meminta respons timbal balik dari partisipan. Hal ini diharapkan dapat memberikan gambaran secara umum bagaimana aktivitas literasi yang sudah dilaksanakan. Selain itu, respons partisipan ini sangat penting dalam mengevaluasi kegiatan literasi secara umum. Berikut beberapa respons dari partisipan yang dipilih secara random.

Gambar 14. Respons Partisipan Berstatus Siswa.

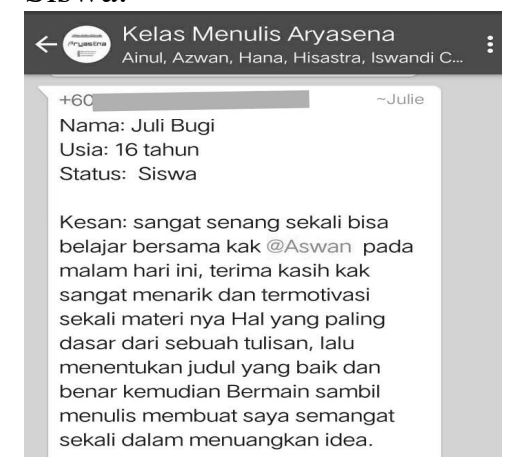

Berdasarkan gambar 14. dapat dikatakan bahwa partisipan yang bergelar siswa merasa sangat senang dengan adanya kegiatan literasi menggunakan
WhatsApp. Hal ini menjadikan partisipan (siswa) merasa termotivasi dalam berkarya di masa pandemik Covid-19. Pembelajaran seperti menulis judul yang benar juga membantu mereka dalam memahami dan mengaplikasikan dalam kegiatan sehari-hari.

Gambar 15. Respons Partisipan Berstatus Mahasiswa

Kelas Menulis Aryasena
Ainul, Azwan, Hana, Hisastra, Iswandi C...
Nama: fitri lathifani
Usia: 20 tahun
Status: Mahasiswa
Kesan: kelas kali ini sangat
menyenangkan pembawaannya
lebih santai dan mudah di pahami.
Banyak pelajaran yg dapat saya
ambil dari kelas ini.
Pesan: Semoga bisa terus berbagi
ilmu pengetahuan. Dan semoga
sukses terus ya kak.

Berdasarkan gambar 15. dapat dikatakan bahwa partisipan yang bergelar mahasiswa beranggapan bahwa pematerian yang dijelaskan melalui WhatsApp mudah dipahami. Selain itu, pembelajaran yang dikuti tidak terlalu kaku sehingga menciptakan suasana yang lebih santai serta tidak terkesan seperti sedang belajar.

Gambar 16. Respons Partisipan Berstatus Ibu Rumah Tangga

Kelas Menulis Aryasena
Ainul, Azwan, Hana, Hisastra, Iswandi C...
Nama: Dea Ayu Wulandari
Usia: 30th
Status:
1.Ibu Rumah Tangga
Kesan:
Sebenarnya kelas ini asyik dan
seru. Tapi sayang,saya yang
tidak optimal mengikutinya
karena sedang sibuk sama
anak. Overall,saya suka dengan
materinya. Terlebih materi
tentang judul. Saya sering
kesulitan menulis judul apalagi
secara teknik. Alhamdulillah saya
mendapat pencerahan


Berdasarkan gambar 16. dapat dikatakan bahwa partisipan yang bergelar ibu rumah tangga memberi respons yang sangat positif. Terlebih lagi pada materi penulisan judul dalam cerita. Hal dasar yang jarang diperhatikan ternyata berdampak pada partisipan yang bergelar ibu rumah tangga. Materi yang dipelajari dapat diaplikasikan pada kehidupan sehari-hari. Misalnya pada penulisan judul dalam status media sosial.

Gambar 17. Respons Partisipan Berstatus Guru

Kelas Menulis Aryasena
Ainul, Azwan, Hana, Hisastra, Iswandi
Nama: Winingsih,S.Pd.
Usia:45;tahun
Status:Guru
Kesan: Kelas menulis ini
sangat menarik karena kita
bisa menuangkan ide-ide dan
curahan hati sehingga menjadi
sebuaj karya yang indah dan
menarik
Pesan:Semoga ada kelas menulis
puisi dan artikel

Berdasarkan gambar 17. dapat dikatakan bahwa partisipan yang bergelar guru memberi respons yang sangat positif. Hal ini dapat dilihat pada kesan yang diberikan partisipan yang merasa aktivitas literasi menggunakan WhatsApp ini sangat menarik karena partisipan dapat menuangkan ide.

Tahapan kelima adalah tahapan terakhir dalam aktivitas literasi menggunakan WhatsApp. Pada kegiatan ini peneliti selaku narasumber memberikan penguatan dari apa yang sudah dipelajari. Selain itu, peneliti dan penyelenggara memberikan apresiasi kepada peserta yang aktif mengikuti kegiatan literasi di grup WhatsApp. Apresiasi yang diberikan adalah sertifikat.

\section{Manfaat Gerakan Literasi Berbasis WhatsApp Selama Masa Pandemi Covid-19}

Berdasarkan pemaparan peneliti pada bagian sebelumnya, dapat dikatakan bahwa menggunakan WhatsApp sebagai media dalam mewujudkan budaya literasi di masa pandemi memiliki banyak manfaat. WhatsApp yang selalu berfungsi sebagai alat untuk berkomunikasi sangat sesuai dijadikan media dalam pembelajaran daring ini. Selain itu, WhatsApp juga memiliki banyak fitur yang dapat membantu pengguna dalam berinteraksi, misalnya mengirim foto, pesan suara, dan sebagainya. Hal inilah yang membuat kegiatan literasi tidak terlalu monoton.

WhatsApp yang biasanya difungsikan sebagai alat untuk berkomunikasi, saat ini dapat dialihfungskan sebagai media pembelajaran daring. Mengingat tidak adanya kegiatan literasi tatap muka, maka salah satu upaya yang dapat menghidupkan budaya literasi di Indonesia adalah dengan memanfaatkan aplikasi yang dekat dengan masyarakat Indonesia.

Manfaat penggunaan WhatsApp ini dapat dirasakan oleh peserta yang mengikuti kelas menulis daring yang diadakan oleh Penerbit Aryasena. Adanya kegiatan literasi ini dapat menambah pengetahuan partisipan seputar materi kepenulisan, salah satunya adalah dalam menulis judul yang baik dan benar. Aplikasi WhatsApp yang notabenenya dekat dengan partisipan membuat kegiatan literasi lebih santai dan berjalan dengan lancar.

Pemanfaatan WhatsApp sebagai media dalam mewujudkan budaya literasi di masa pandemi Covid-19 ini dapat memberi gambaran pada pegiat literasi lainnya dalam melakukan gerakan di masa pandemi ini. Hasil dari pemanfaatan WhatsApp dalam mewujudkan budaya literasi ini menjadi masukan kepada pemerintah untuk mendorong pegiat literasi dalam memanfaatkan teknologi. 
Berdasarkan respons positif partisipan, pemanfaatan WhatsApp ni sangat bermanfaat dalam kegiatan literasi khususnya di masa pandemi Covid-19. Hasil dari pembahasan ini dapat memberi gambaran kepada pegiat literasi lainnya untuk bisa memanfaatkan media yang dekat dengan partisipan. Media yang dekat dengan partisipan dapat membangun konteks percakapan yang tidak terlalu formal sehingga kegiatan literasi berjalan dengan lancar dan sesuai harapan.

Salah satu kegiatan literasi yang dapat dimanfaatkan melalui WhatsApp adalah aktivitas menulis judul yang benar. Hal tersebut terdengar sederhana. Namun, menurut respons partisipan yang sudah dibahas pada bagian sebelumnya, materi penulisan judul yang benar dapat menambah pengetahuan dasar partisipan dalam menulis judul di kehidupan sehari-hari. Misalnya, bagi partisipan bergelar siswa dapat dimanfaatkan untuk menulis judul cerita dalam tugas-tugas sekolah. Begitu pun dengan partisipan yang bergelar mahasiswa. Selain itu, partisipan yang bergelar guru dapat menambah pengetahuan dan disebarkan kepada siswa-siswa di sekolah. Adapun partisipan bergelar ibu rumah tangga dapat menulis judul yang benar dalam status di media sosial.

Pandemi Covid-19 seharusnya bukanlah penghalang untuk terus memajukan budaya literasi yang ada di Indonesia. Mengingat tingkat literasi orang Indonesia yang selalu dikatakan rendah, maka segala upaya yang dapat meningkat literasi harus dilakukan. Membaca 15 menit tidak bisa lagi diandalkan saat ini, pegiat literasi harus cari strategi yang sesuai dengan perkembangan zaman saat ini. Arus globalisasi yang terjadi saat ini menuntut semua masyarakat dunia ikut berpartisipasi dalam menuju masa depan yang cerah.

\section{Kelebihan dan Kelemahan Menggunakan WhatsApp sebagai Media dalam Kegiatan Literasi di Masa Pandemi}

Berdasarkan hasil dari penelitian ini, ditemukan beberapa kelebihan dan kelemahan yang dapat menjadi poin penting dalam penelitian lanjutan. Adapun kelebihan dan kelemahan dalam menggunakan aplikasi WhatsApp dijelaskan sebagai berikut.

Tabel 2. Perbandingan Kelebihan dan Kekurangan

\begin{tabular}{|l|l|}
\hline \multicolumn{1}{|c|}{ Kelebihan } & \multicolumn{1}{c|}{ Kekurangan } \\
\hline $\begin{array}{l}\text { Pegiat literasi mudah } \\
\text { mendapatkan partisipan } \\
\text { dari berbagai daerah. }\end{array}$ & $\begin{array}{l}\text { Partisipan yang } \\
\text { berasal dari daerah } \\
\text { terpencil sulit } \\
\text { mendapatkat sinyal. }\end{array}$ \\
\hline $\begin{array}{l}\text { Aplikasi WhatsApp } \\
\text { mudah didapatkan dan } \\
\text { digunakan. }\end{array}$ & $\begin{array}{l}\text { Grup WhatsApp } \\
\text { melimitasi anggota } \\
\text { grup. }\end{array}$ \\
\hline $\begin{array}{l}\text { Tidak banyak biaya yang } \\
\text { digunakan. }\end{array}$ & \\
\hline $\begin{array}{l}\text { Banyak fitur yang dapat } \\
\text { digunakan dalam } \\
\text { menunjang kegiatan } \\
\text { literasi. }\end{array}$ & \\
\hline $\begin{array}{l}\text { Mudah dalam } \\
\text { menyosialisasikan } \\
\text { kegiatan ke publik. }\end{array}$ & \\
\hline
\end{tabular}

Berdasarkan tabel di atas, dapat dibandingkan antara kelebihan dan kekurangan dari pemanfaatan WhatsApp sebagai media dalam kegiatan literasi di masa pandemi. Terlihat jelas bahwa pemanfaatan WhatsApp dalam kegiatan literasi ini memiliki kelebihan yang dapat diandalkan bagi pegiat literasi. Seperti mudah menyosialisasikan kegiatan, aplikasi mudah diakses, tidak banyak biaya yang digunakan, fitur dalam aplikasi WhatsApp dapat menunjang kegiatan, serta pegiat literasi mudah mendapatkan partisipan dari berbagai daerah. Meskipun demikian, tetap ada kelemahan yang harus diperhatikan oleh pegiat literasi. Pertama, partisipan yang berasal dari daerah terpencil sulit untuk mendapatkan sinyal. Tidak dimungkiri bahwa hal inilah yang 
menjadi salah satu penghambat dalam pembelajaran daring. Selain itu, grup WhatsApp memiliki limitasi partisipan sehingga tidak memungkinkan semua orang dapat bergabung dalam satu waktu. Namun, kelemahan tetaplah tidak menjadi penghalang dalam mewujudkan budaya literasi di masa pandemi ini.

\section{KESIMPULAN}

Berdasarkan hasil dari pembahasan yang telah diuraikan pada bagian sebelumnya, dapat ditarik beberapa simpulan. Pertama, WhatsApp dapat dijadikan media dalam mewujudkan budaya litterasi di masa pandemi Covid19 karena WhatsApp merupakan salah satu media yang dekat dengan partisipan di kehidupan sehari-hari. Kedua, stimulus berupa gambar dapat membantu dan memantik partisipan dalam menuangkan ide. Adanya stimulus yang tepat, dapat menarik perhatian partisipan dalam berpartisipasi aktif. Ketiga, melalui respons dari partisipan, dapat dikatakan bahwa partisipan merasa senang dan termotivasi dengan adanya kegiatan literasi di masa pandemi Covid-19 ini. Berdasarkan simpulan tersebut, perlu kirannya dilakukan penelitian lanjutan untuk mengetahui efektivitas penggunaan WhatsApp sebagai media di masa pandemi Covid-19. Dengan demikian, dapat diketahui efektivitas penggunaan WhatsApp dalam aktivitas literasi di masa pandemi Covid-19.

\section{DAFTAR PUSTAKA}

Adelore, O. (2017). Using whatsapp mobile application as tutorial delivery tool for advanced level learners in adult literacy programmes: Lessons learned. African Journal For The Psychological Study Of Social Issues, 20(1), 131-139.

AlFaris, E., Irfan, F., Ponnamperuma, G., Jamal, A., Van der Vleuten, C.,
Al Maflehi, N., ... \& Ahmed, A. M. (2018). The pattern of social media use and its association with academic performance among medical students. Medical teacher, 40(sup1), 77-82. DOI: https://doi.org/10.1080/0142159 X.2018.1465536

Aswan. (2020). Implementasi gerakan literasi sekolah di community learning center sebagai upaya meningkatkan kosakata bahasa indonesia siswa. KLITIKA: Jurnal Ilmiah Pendidikan Bahasa dan Sastra Indonesia, 2(2), 110.

Aulia, N. L., Aswan., \& Naufalia, A. (2020). Pendidikan berbasis produk dalam meningkatkan literasi anak menuju generasi emas 2045. KLITIKA: Jurnal Ilmiah Pendidikan Bahasa dan Sastra Indonesia, 2(1), 55-64. DOI:

http://dx.doi.org/10.32585/klitika .v2i1.709.

Budhianto, Y. (2018). Pembelajaran bahasa sebagai upaya meningkatkan kemampuan literasi siswa. Fon: Jurnal Pendidikan Bahasa dan Sastra Indonesia, 13(2), 171-181. DOI: https://doi.org/10.25134/fjp bsi.v13i2.1550

Chaudron, S. (2015). Young children (08) and digital technology: $A$ qualitative exploratory study across seven countries (Report EUR 27052). Luxembourg: Publications Office of the European Union.

Costa-Sánchez, C., \& Guerrero-Pico, M. (2020). What is whatsapp for? Developing transmedia skills and informal learning strategies through the use of whatsapp-a case study with teenagers from spain. Social Media + Society, 
$1-11$

$10.1177 / 2056305120942886$

Creswell, J. W. (2009). Research design qualitative, quantitative, and mixed methods approaches. University of Nebraska-Lincoln: SAGE Publications.

Danby, S. J., Fleer M, Davidson, C., \& Hatzigianni, M. (Eds). (2018) Digital childhoods. Technologies and children's everyday lives. Singapore: Springer.

Dhawan, S. (2020). Online learning: A panacea in the time of COVID-19 crisis. Journal of Educational Technology Systems, 1-18. DOI: https://doi.org/10.1177/00472395 20934018

Erstad, O., Flewitt, R., KümmerlingMeibauer, B., \& Pereira, I. S . P. (Eds). (2020). The routlegde handbook of digital literacies in early childhood. London: Routledge.

Fatia, S. N. (2020, September 1). [UPDATE] Kasus Virus Corona Indonesia per 1 September 2020 Naik Jadi 177.571 Jiwa. Pikiran Rakyat. DOI:

https://www.pikiran-

rakyat.com/nasional/pr-

01711869/update-kasus-viruscorona-indonesia-per-1september-2020-naik-jadi177571-jiwa

Fattah, S. F. E. S. A. (2015). The effectiveness of using whatsapp messenger as one of mobile learning techniques to develop students' writing Skills. Journal of Education and Practice, 6(32), 115-127.

Fleer, M. (2018). Examining the psychological content of digital play through hedegaard's model of child development. Learning,
Culture, and Social Interaction. DOI: 10.1016/j.lcsi.2018.04.006

Flewitt, R., Messer, D., \& Kucirkova, N. (2015). New directions for early literacy in a digital age: The iPad. Journal of Early Childhood Literacy, 15(3), 289-310. https://doi.org/10.1177/14687984 14533560

Ganasegerana, K., Renganathand, P., Rashide, A., \& Al-Dubai, S. A. R. (2017). The m-Health revolution: Exploring perceived benefits of whatsappuse in clinical practice. International Journal of Medical Informatics, 145-151. DOI: http://dx.doi.org/10.1016/j.ijmedi nf.2016.10.013

Goyal, A., Tanveer, N., \& Sharma, P. (2017). WhatsApp for teaching pathology postgraduates: A pilot study. Journal of pathology informatics, $8, \quad 6 . \quad$ DOI: https://doi.org/10.4103/21533539.201111

Ihsanuddin. (2020, Maret 2). Lengkap kasus pertama virus corona di indonesia. Kompas.com. https://nasional.kompas.com/read /2020/03/03/06314981/faktalengkap-kasus-pertama-viruscorona-di-indonesia

Kumpulainen, K., Sairanen, H., \& Nordstrom, A. (2020). Young children's digital literacy practices in the sociocultural contexts of their homes. Journal of Early Childhood Literacy, 128. DOI: $10.1177 / 1468798420925116$

Kurniati, M., \& Nuryani. (2020). Pengaruh sosial media youtube terhadap pemerolehan bahasa anak usia 3-4 tahun (studi pada anak speech delay). Fon: Jurnal Pendidikan Bahasa dan Sastra Indonesia, 16(1), 29-38. DOI: 
https://doi.org/10.25134/fjpbsi.v1 $6 \mathrm{i} 1.2494$

Marsh, J., Hannon, P., Lewis, M., \& Ritchie, L. (2017) Young children's initiation into family literacy practices in the digital age. Journal of Early Childhood Research, 15(1), 47-60. DOI: https://doi.org/10.1177/1476718 X15582095

Mihailidis, P. (2016). Digital curation and digital literacy: Evaluating the role of curation in developing critical literacies for participation in digital culture. E-Learning and Digital Media, 1-6. DOI: 10.1177/2042753016631868

Moleong, J. L. (2012). Metodologi penelitian kualitatif. Bandung: Rosdakarya.

Nelson, E. L., Perry, M., \& Rogers, T. (2020. Introducing offlineness: Theorizing (digital) literacy engagements. Journal of Literacy Research, 1-7.

O'Sullivan, D., Rahamathulla, M., \& Pawar, M. (2020). The impact and implications of COVID-19: An australian perspective. The International Journal of Community and Social Development, 2(2), 134-151. DOI: https://doi.org/10.1177/25166026 20937922

Pustikayasa, I. M. (2019). Grup whatsapp sebagai media pembelajaran. Widya Genitri : Jurnal Ilmiah Pendidikan, Agama Dan Kebudayaan Hindu, 10(2), 53-62.

Rahmansari, R. (2017). Penggunaan aplikasi whatsapp dalam komunikasi organisasi pegawai dinas. Jurnal Ilmiah Manajemen Publik dan Kebijakan Sosial, 1(2), $77-90$.
DOI:http://dx.doi.org/10.25139/j mnegara.v1i2.788

Raiman, L., Antbring, R., \& Mahmood, A. (2017). WhatsApp messenger as a tool to supplement medical education for medical students on clinical attachment. BMC medical education, 17(1), 1-9. DOI:https://doi.org/10.1186/s129 09-017-0855-x

Scolari, C. A., \& Contreras-Espinosa, R. S. (2019). How do teens learn to play video games? Informal learning strategies and video game literacy. Journal of Information Literacy, 13(1), 45$61 . \quad$ DOI: https://doi.org/10.11645/13.1.235 8

Suwandi, S. (2018). Pembelajaran bahasa indonesia yang mencerdaskan dan tanggung jawab menghasilkan generasi literat. Fon ; Jurnal Pendidikan Bahasa dan Sastra Indonesia, 13(2). 117.

Wijaya, A. (2018). Students' responses toward the use of whatsapp in learning. Journal of Teaching \& Learning English in Multicultural Contexts, 2(1), 46-55.

Choo, S. (2004). Investigating Ideology in the Literature curriculum in Singapore. Unpublished master's thesis. Department of English Language and Literature: National University of Singapore.

Flower, L., \& Hayes, J. R. (2008). A cognitive process theory of writing. College Composition and Communication, 32(4), 365387.

Curriculum Planning and Development Division. (2007). Literature in English, teaching syllabus. Ministry of Education: Singapor. 